\title{
Giffordian post-pastoral and loss of innocence in William Blake's the little boy lost and the little boy found
}

\author{
Mohsen Zohrab Baigy ${ }^{1, ~ *}$, Bahman Zarrinjooee ${ }^{2}$ \\ ${ }^{1}$ M.A. Student of English Language and Literature, Islamic Azad University, Boroujerd Branch, Iran \\ ${ }^{2}$ Assistant Professor of English Language and Literature, Islamic Azad University, Boroujerd Branch, Iran \\ Email address: \\ mohsen_zohrabbeigy@yahoo.com (M. Zohrab Baigy), bahmanzarrinjooee@yahoo.com (B. Zarrinjooee)
}

\section{To cite this article:}

Mohsen Zohrab Baigy, Bahman Zarrinjooee. Giffordian Post-pastoral and Loss of Innocence in William Blake's the Little Boy Lost and the Little Boy Found. International Journal of Literature and Arts. Vol. 2, No. 2, 2014; pp. 35-39. doi: 10.11648/j.ijla.20140202.12

\begin{abstract}
This article aims to explore loss of innocence in William Blake's the Little Boy Lost and the Little Boy Found, from Songs of Innocence (1789) based on Gifordian Post-pastoral theory through interpreting three fundamental features. The analysis of these poems from this perspective considers the exploitation of the planet similar to the exploitation of minorities, awareness of nature as culture and of culture as nature, and the convergence of consciousness and conscience. Regarding Gifordian Post-pastoral attitudes, one might find how Blake dealt with the notions such as Innocence and Industrialization, which have been interlinked, in his poems. Blake represents a situation in which the state of innocent children is thoughtfully portrayed against the economic and political dominance of British capitalism. Having an eye on the viewpoints of Raymond Williams, (1921-1988), this paper clarifies the destructive function of capitalism which subjugates, exploits and victimizes the children in an unbearable working condition as cheap labours. Moreover, this paper sheds more light on Blake's poems as the implication of New Jerusalem to that quality of unidealised awe, and shows how Blake argues that the pure nature of all children is supposed to be admired as equal to culture. Finally, this article deals with the spiritual Heaven as compensation for the alienation of innocent children throughout the world of materiality.
\end{abstract}

Keywords: Post-pastoral, Innocence, Industrialization, Exploitation, Capitalism, New Jerusalem, Heaven

\section{Introduction}

Loss of innocence is a kind of transfiguration, which suggests the outburst of the loss of happiness for those children who lost their world of childhood due to the influx of industrialization. The destructive impacts of Industrial Revolution across the unsafe working conditions, and on the life of the hapless children, which harm them physically, morally, and mentally, lead humanity toward "a need [for] post-pastoral literature that will help [man] understand [such a] dialectical experience and how [he] can take responsibility for it" (Gifford174). The ecocritic Terry Gifford introduces the term 'Post-pastoral', away from dialectics of the pastoral and anti-pastoral as a "literature that is aware of the anti-pastoral and of the conventional illusions upon which Arcadia is premised, but which finds a language to outflank those dangers with a vision of accommodated humans, at home in the very world they thought themselves alienated from by their possession of language" (ibid). To bridge the gap between his ideas of anti-pastoral and post-pastoral, "ecocriticism may be the frame of our age, informed with a new kind of concern for 'environment', rather than 'countryside' or 'landscape' or the 'bucolic', but we cannot pretend that there have not been changes in our knowledge, attitudes and ideology" (147).

The Industrial Revolution greatly influenced Blake's poetry as he attacks its nature and effects on humanity. In his subject of Industrial Revolution, the innocent children from black and white races are often overlooked. They are often viewed as commodities, or source of incomes for their poor families. During Blake's time, many of them are treated like animals, or worse than animals. William Blake (1757-1827) throughout his poetry particularly the Little Boy Lost portrays a close relationship between the transfiguration of the pastoral world and the innocent children as the subjects to exploitation. On the other hand, his imageries in the Little Boy Found suggest the idea of New Jerusalem as his ideal culture for them. More to the point, Blake feels he is responsible for constructing a sublime Heaven for the 
exploited children as a kind of spiritual compensation in their painful life. Due to Blake's concern about the unbearable condition of the children within the industrial system of England, the poems, the Little Boy Lost and the Little Boy Found from Songs of Innocence (1789), precisely have been chosen to be dealt with form of post-pastoral perspective.

The main argument in this article is focused on the importance of three out of six crucial features of Gifford's post-pastoral theory which include the awareness of natural exploitation as equal to the exploitation of minorities (the innocent children), the awareness of culture as nature, follows with nature as culture, and awareness of consciousness as a tool to give conscience to human. The poems subsequently will be analysed form viewpoints of critics like Terry Gifford (1946- ), Raymond Williams (1921-1988), and Leo Marx (1919- ).

\section{Children in Hell}

Since industrialization happened in the late eighteenth and early nineteenth centuries, the shape of agricultural lands was transfigured to mechanized societies, therefore, "the age of machinery transforms men into objects" (Marx 298). In contrast to the continuous moaning of innocent creatures throughout the environmental crisis, it is clear that such an age of machinery has allowed man to chop down massive innocent trees and destroy natural resources. Due to the emergence of industrialism, the harsh sound of choppers and chain saws marks the beginning of a new epoch of cruelty against environment. Consequently, consuming the mineral resources can be destructive as it diverts courses of the natural life. Energy production can create other kinds of damage as well. Oil spills destroy marine life. Power plants burning coal and gas produce pollution along with electricity.

Pollution is also harmful to humankind as well as the natural environment. There is no doubt that increasing pollution of factories results in degradation of environment. As Marx argues, "the wilderness, the ocean, the Fish, and even the hunted whale and other resources are destroyed and destruction [is] due to Industrial System" (293). It is notable to cites that "when the pastoral order is destroyed, creation is 'stinted', the brook is 'choked', the cry of bitten is 'hollow' the lapwing's cries 'unvaried" (qtd. in Gifford 123). Not only was the transformation of natural environment the result of Industrial Revolution, it was "based on highly developed agrarian capitalism, with a very early disappearance of the traditional peasantry" (Williams 1973: 2). As a term, capitalism is "a particular economic system began to appear in English form eC19, and simultaneously in French and German" (Williams 1976: 50). It is a "[ [..] particular form of centralized ownership of the means of production, carrying with it the system of wage labour" (ibid). The recognition of individual rights within such a system subsequently elaborated by William Blake concerning the transfiguration face of natural environment across the pastoral life of all innocent children.

The Little Boy Lost exactly displays what has happened in the misfortune life of childlike innocence:

Father, father, where are you going?

Oh do not walk so fast!

Speak, father, speak to you little boy,

Or else I shall be lost.

The night was dark, no father was there,

The child was wet with dew;

The mire was deep, and the child did Weep,

And away the vapour flew. (TLBL Lines 1-8)

This poem accords with the beginning of children's dangerous journey into a world of oppression and false ideas. In this poem, the gloomy position of the child's life attracts our attention toward the first crucial feature of Gifford's post-pastoral criteria: "the exploitation of the planet is of the same mindset as the exploitation of women and minorities" (164). Blake's choices of diction smart play on the child's words, 'Father, father, where are you going', or 'I shall be lost', in the first stanza, because the painful experience of the new world in the child's fancy is out of control.

In the second stanza, Blake indirectly notifies the readers about an environmental crisis and subsequently the profit of trade and of a colonial exploitation, since the gentle emotions are surrounded by melancholic atmospheres such as 'The night was dark, no father was there' and 'The mire was deep, and the child did weep'. These lines due to the outburst of technology display that the transfiguration of natural world parallels the beginning of adult's experience regarding passionless sensations. When industrial system specialized and mechanized productions during the industrial revolution, human life lost its moral values due to extra labours in the cities, which resulted in lower wages, widespread poverty, and child labour. More to the point, under the authority of capitalism in England, the mistreatment, and dehumanization have been most intensified and most obvious. Within such a system, the innocent children, like the minorities, men and women from the proletarian class in society have often been subject to exploitation by "forced labour, or 'bought and sold like beasts" (Williams 1973: 37). As a result, child labour as an unsafe and obnoxious phenomenon that threatens the children's health was widespread throughout the industrialized England.

During industrialization, the most critical aspect of the poor Law act is the management of workhouses, where "the workhouses organized the response to poverty, and, on the other side of the coin, it linked poverty to labour in new ways, so that the harrying of what was called vagrancy, itself the result of a socially created disturbance and mobility, became, in its turn, a moral duty" (Williams 1973: 83). Consequently, many of the child labourers are forced to 
work in workhouses as chimneysweepers, or servants at the persistence of their parents. As chimneysweepers, many of these children not only were wounded from serious falls but also were exploited by their employers. They were excluded "not only just [from] boyhood innocence, but of hope, rights, and freedom [...] that were the commons" (Gifford 128). Most of these children were labelled, as 'child labourers', because they would help their parents as the sources of income at homes, in workhouses, or factories. Below is a sketch showing the innocent child in a workplace during industrial revolution:

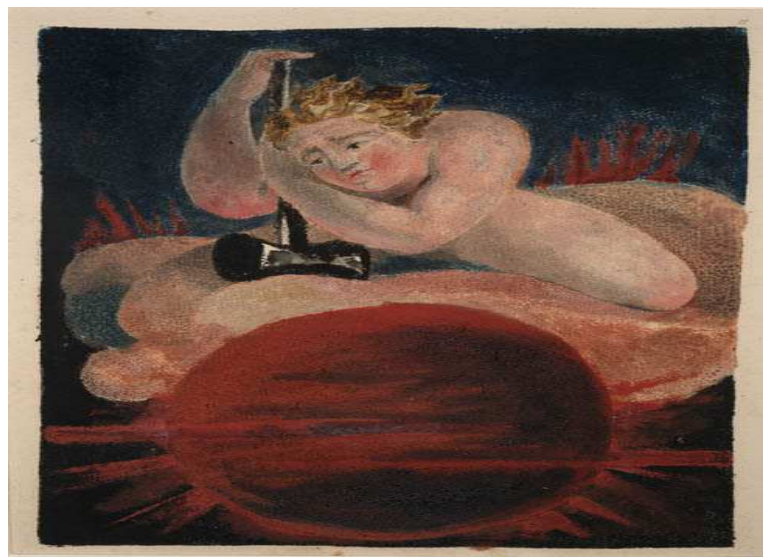

Figure 1. A Child Labour at the Statues of Industrialization.

Indeed, the oppressive power of capitalist environment utilizes economic resources while the poor men, women, and children were subjected to the exploitation and unbearable living conditions:

Capitalism has in this sense always been an ambiguous process: increasing real wealth but distributing it unevenly [...]. There was thus a continuing contrast between the extraordinary improvement of the land and the social consequences of just this process, in the dispossessed and the vagrants, and the old, the sick, the disabled, the nursing mothers, the children who, unable to work in these terms, were seen as merely negative, an unwanted burden. (Williams 1973: 82).

Blake protests against power and the insatiable restless movement of industrial capitalism, which actually maintains the immorality of exploitation which in Williams words is: "the destructive general condition [which leads] to an exploitation of labour or of the minds of others, and this exploitation is itself only possible of the stupidity, indifference or brutality of the exploited" (270). In Blake's poem, the word 'Night', in the second stanza, exactly shows the child's fear of losing his father in the world of darkness due to his painful experiences. The child is represented as a pitiless creature who has been sold to the businesspersons due to the benefit of cheap labours. The children are often among the most abusing work forces through being exploited in hellholes. For instance, the tough condition of the life of a chimneysweeper would be more problematic, when he/she with his/her delicate body was forced to climb narrow hot flues and clean ashes. There is no wonder that they may encounter an unwelcomed death since the fire has burned below in the fireplaces. They often live in the dirty bedchambers which seem like pig houses, not suitable for human. The words such as 'Mire' and 'Vapour' in the second stanza exactly show the striving of young boys to survive within the unbearable condition of bedchambers. Such conditions lead to disease and ultimately to high death rates among them.

It is important to note that poor working conditions throughout the misfortune life of the innocent children often resulted in accidents, which led to physical injuries and even death while "many of these accidents occurred because the children were too tired and none of the machines had guards" ("Styal Mill" 17). More to the point, it seems that malnutrition is another problem around the life of innocent children. They are even more vulnerable to malnutrition or even death since there are no suitable and sufficient foods. Williams argues:

In the midst of the most extraordinary abundance, here are men, women and children dying of starvation; and running alongside of the splendid chariot, with its gilded equipages, its silken linings, and the liveried footman, are poor, forlorn, friendless, almost naked wretches, looking like the mere fragments of humanity" ( 228).

Williams's declaration indicates that the innocent life of childhood has been corrupted by something evil. Unfortunately, laws to protect them from abusing, either sexual or physical, are weak or non-existent. William Blake uses his poem as a weapon to attacks the system of capitalism in England, regarding the increase of social injustice and hypocrisy in social values. In addition, this poem is helpful in implementing social reforms, which shows Blake's readers the need for proper laws and factory acts to prohibit the employment of children.

\section{Children in Heaven}

Following the crucial descriptions about the exploitation of the innocent children, Blake encourages his readers to think of themselves as connected to benevolent nurturing of nature. Blake's readers see all of humanity being united to shape the pastoral ideal as a hopeful state for the hapless children. In the first and second stanzas of the Little Boy Found, the readers can perceive Blake's humanistic sensation as being united to shape the grandeur state of them across the influx of industrialization:

The little boy lost in the lonely fen,

Led by the wandering light,

Began to cry, but God, ever nigh,

Appeared like his father, in white.

He Kissed the child, and by the hand led,

And to his mother brought, 
Who in sorrow pale, through the Lonely dale,

The Little boy weeping sought. (TLBF lines 1-8)

This poem deals with the second fundamental feature of Gifordian Post-pastoral argument regarding "an awareness of both nature as culture and of culture as nature" (Gifford 161), which adds a moral imperative of responsibility to that quality of unidealised awe. In the study of these stanzas, by using heavenly images such as 'wandering Light', and 'white', Blake not only portrays the strong union affection that exists between God and the innocent children but also he shows the only true salvation for humanity. In addition, by giving these humbling senses of wonder and majesty of the natural world which overwhelmed by the awe and reverence across these lines, Blake recommends Romantic sensibility and sublimity or "the inimitable softness" (Marx 215). His sublimity indicates the 'ever nigh, appeared like his father, in white in the first' or 'He kissed the child' equal to the ideal culture.

Depiction of the sublimity refers to spiritual awakening as the spiritual salvation for the uselessness and emptiness of life, which always resulted in sterility and spiritual death-in-life of human, portrayed in Blake's paintings. More to the point, these perfect imageries display Blake's responsibility toward the pure children who were like culture because they are a part of the whole. Blake's ideal culture would be an Arcadia vision as an implication for a New Jerusalem, where "The tall air smelt of summer, it smelt of ripeness, We lay stretched out in plenty, pears at our feet, Apples at our sides and plumtrees reaching down, Branches pulled earthward by the weight of fruit" (qtd. in Gifford 16). Arcadia in Blake's viewpoint is "the perfect location for a poetic paradise, a literary construct of a past Golden Age in which to retreat by linguistic idealization" (ibid). Below is a picture of the Golden Eden:

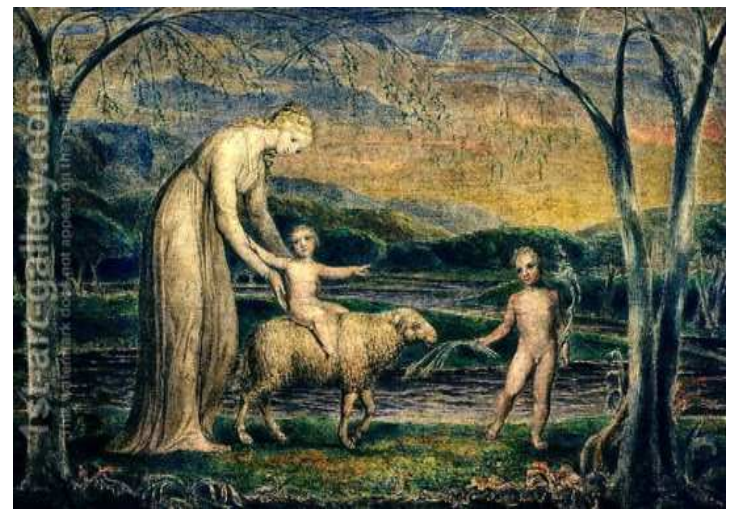

Figure 2. The Happy Child Riding a Lamb.

From the above picture, one can also notice that the Blake's Arcadia could be "a childhood of "innocence and ease', where 'decency' is the key value" (Gifford 43). It is believed that the perpetual peace or the eternal life in Heaven is not only a compensation for the voices of weeping, crying, lamentation, and their strong pains in life but also ironically calls man to dominate the significant state of children in the same way he treats the values of progressing technologies. Although Blake suggests that there is spiritual heaven as a compensation for heavenly children, there is also an earthy heaven; in other words, an ideal culture for them within the physical world. Consequently, his imageries in this poem give a moral responsibility toward the state of innocent children in an ideal society. This is what Gifford calls "as 'accommodated man' in natural world as much as in the social world" (149).

The Little Boy found also works with environmental consciousness and concerns with the consequences of urbanization on traditionally agricultural societies. Regarding the moral comprehensive concept of the poem, Blake's readers might find the notion of 'God' as an allegory to show His love and care that is objects of God's love and concern. The moral tone of the poem is carried by Blake's scholarly choice of imageries. Here, Blake's readers are directed toward the Christian conception of God while the child 'Began to cry', and God 'ever nigh', 'Appeared like his father, in white'. To Blake, the holly image of 'God' appears in the figure of Jesus Christ. In Christ's heart, the full of everlasting light of God shows the only right way for those who have suffered like the innocent children among the materialistic world. The kingdom of God is truly established to reign peacefully and in continually righteousness for the young children around Christ. More to the point, Blake feels he is responsible to give an eternal life as a hopeful state in the kingdom of heaven when they are damaged by such circumstances. These descriptions attract Blake's reader's attention to the other crucial feature of Gifford's post-pastoral criteria: "it is our consciousness which gives us our conscience, our ability to take responsibility for our behavior towards the other species of the plain and towards the plain itself" (163). Since consciousness of man as a source of alienation brings the social and environmental decline, the children's alienation also is because of the world of experience. They are also alienated by the harsh reality of long hours of working in the coalmines or horrible conditions. In this poem, consciousness is transformed into right conscience similar to the dark conditions of the poor children which were transformed into total spiritual hope and they 'Led by the wandering light' toward His paradise. It is important to mention that the third and fourth features of Post-pastoral criteria are pursuant to each other. Blake as a humanist poet is responsible to promise them there will be an end to the temporal power of the transgressors. He strives to indicate the message that there should be no discrimination of any kind against those living in the same country, or generally, on the same planet.

\section{Conclusion}

Gifford identifies six fundamental aspects of his Post-pastoral arguments, which build on ecocritical theory, encompasses the majority of Blake's Songs of Innocence and Songs of Experience (1992), but three of them are being crucial to understand the term. The three prominent features include the exploitation of natural world parallel the 
exploitation of the hapless children as minorities, the need for culture as nature and vice versa, and the need for consciences to heal consciousness as a source of alienation. William Blake reinforced these ideas while the hypocrisy in capitalism in England has overlooked regarding the condition of poor people. More to the point, he protests that the purity of innocent children like the gentility of the pure nature has been blurred by darkness and filthiness since industrial revolution.

The Little Boy Lost indicates the possibility of loss of innocence, which results in taking advantage of cheap child labour and exploitation in the industrialized system as the most valuable things for businesspersons. The children were forced to work during very long hours in horrible conditions which end in awful disasters. Whereas, the Little Boy Found shows a possibility of New Jerusalem as equal as the ideal culture. More to the point, this poem shows a possibility of God's promise of Paradise in Heaven for those young innocent children who tolerate the most sufferings within the obscurity of the world.

\section{References}

[1] Blake, William. Songs of Innocence and Songs of Experience. Ed. Philip Smith. Dover Publications; 1992.

[2] Gifford, Terry. Pastoral. New York: Routledge, 1999.

[3] Marx, Leo. The Machine in the Garden: Technology and the Pastoral Ideal in America. Oxford: Oxford Up, 1964.

[4] Williams Raymond. The Country and the City. New York: Oxford UP, 1973.

[5] Keywords: A Vocabulary of Culture and Society. New York: Oxford UP, 1976.

[6] "Styal Mill." Year 10 Coursework Booklet. Fairfield High. 12 Sep 2013 